\title{
GM 型冷凍機を用いたネオンの三重点の実現
}

\author{
櫻 井 弘 久*
}

Precise Realization of the Triple Point of Neon Using a Closed Cycle GM Refrigerator

Hirohisa SAKURAI*

\begin{abstract}
The triple point of neon is realized calorimetrically using a closed cycle refrigerator (a Gifford-McMahon type refrigerator). The usage of the closed cycle refrigerator combined with a closed fixed-point cell is found not only to be the easiest and the simplest way to realize the fixed points in both handling and operation compared with the traditional cryogenic technique using liquid helium, but to have a potential to be one of the most accurate realizing methods. The standard uncertainty of this system in calibrating standard platinum resistance thermometers at the triple point of natural neon is estimated to be $0.056 \mathrm{mK}$. The highly stable low temperature environment of the refrigerator revealed that natural neon has long relaxation time constants for the isotopic spatial equilibration after pulse heating.
\end{abstract}

Key Words: triple point of neon, GM refrigerator, ITS-90

\section{1.はじめに}

ネオンの三重点は 1990 年国際温度目盛 ${ }^{1) \sim 3)}$ (以下, ITS90 と略す)の定義定点の一つであり, その付与值は $24.5561 \mathrm{~K}$ である。ネオンの三重点は低温域での温度標準の設定，すな わち，白金抵抗温度計や補間用気体温度計の校正には不可欠 な温度定点の一つである.

従来, 水素, ネオン, 酸素などの三重点は, 液体へリウム を用いた低温環境で気休試料を液化, 固化させて融解曲線を 測定することにより実現されていた4) 6)。これらの装置の設 計や操作は複雑で，低温独特の技術やノウハウが必要であっ た. 一方, 装置の設計や操作の簡略化などを目的に, 最近, 低温定点をクローズドサイクル冷凍機で実現することが試み られている7) 一9).

水素の三重点については Gifford-McMahon 型冷凍機（以 下，GM 型冷凍機と略す）を用いて，より簡便で，かっ，高 い測定精度での実現が可能であることを報告した ${ }^{7), 8) ， ネ オ ~}$ ンに関しても同様に，GM 型冷凍機と密封セルを組み合わせ ることにより，凝固操作や融解曲線の測定などほとんど全て の操作を自動化することが可能であった，簡便に三重点が実 現でき，しかも測定精度に関しても，従来の液体へリウム槽 を使う方法より良い結果が得られた。

更に，液体へリウム槽では蒸発に伴なう液面の低下などに よる測定時間の制約や温度分布の変動があるのに対し，冷凍 機では運転時間に制約がなく，また，冷凍機内の温度が冷凍 能力で決まるため長時間にわたって安定であった。この結果， ネオンの同位体組成に起因すると思われる緩和時問の長い現 象が観測された。ここでは GM 型冷凍機を用いて，ネオンの 三重点を精密に実現した結果とその定点を用いて白金抵抗温

\footnotetext{
* 計量研究所 つくば市梅園 1-1-4

* National Research Laboratory of Metrology, Tsukuba (Received July 13, 1998)

(Revised October 12, 1998)
}

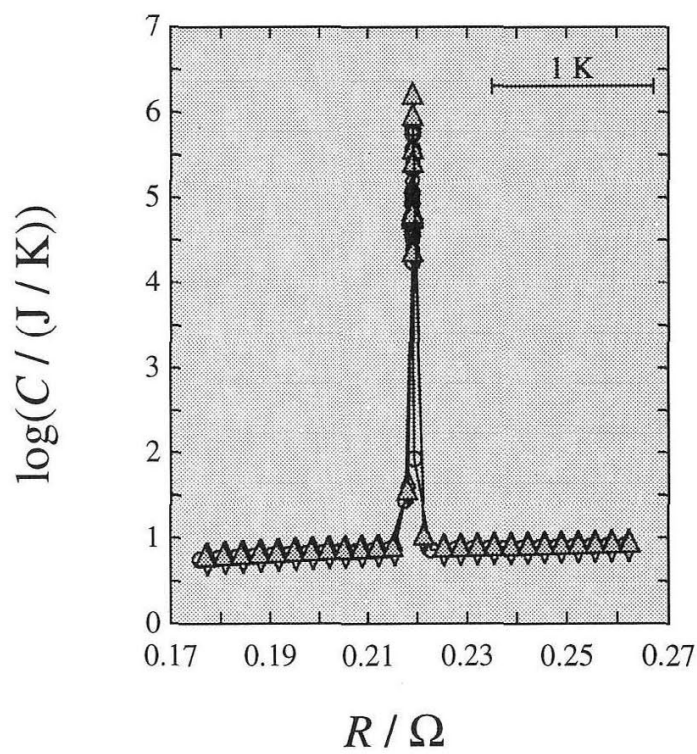

Fig. 1 Heat capacity, $C$, of the neon cell, Ne-7802, at temperatures near the triple point measured by a standard platinum resistance thermometer

度計を校正する際の不確かさについて報告する。

\section{2. 装置および測定法}

低温環境を実現するためのクローズドサイクル冷凍機は， すでに報告した水素の三重点の実現に使用した装置7),8)を使 い, 水素の三重点セルの代りにネオンの密封三重点セル（Ne$7802^{5), 6)}$ ) を用いた。 このセル内の試料の量は約 $58 \mathrm{mmol}$ で, 融解熱は約 $19.5 \mathrm{~J}$ である. 定点セルの取り付け法, 温度 制御法は水素の三重点と同様に, 定点セルを系で吊し, 3 対 の金鉄/クロメル熱電対をシリーズに接続して断熱制御した。 また，セルの冷却には熱交換ガスを使用せず，測定導線およ び保持パイプ類による固体伝導のみを使用し，冷凍機の運転 開始以外の全ての操作を自動化した．なお，パルス加熱した 


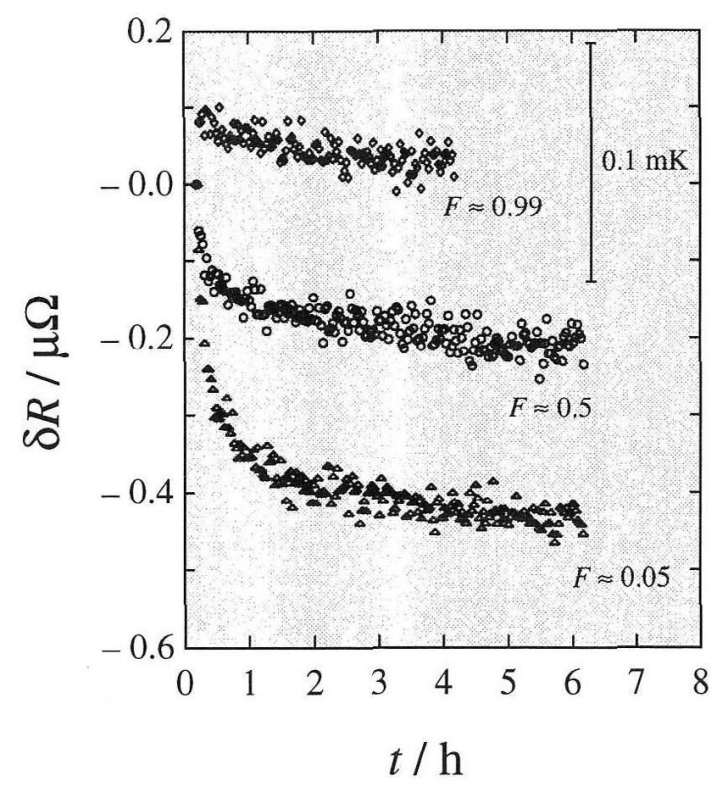

Fig. 2 Temperature changes of the neon cell for thermal equilibration during the melting curve measurement. $t$ is the time measured from the end of heating and $\delta R$ is the difference in resistance from the value at $t=0$.

後, 融解温度以外では約 $20 \mathrm{~min}$ 後に白金抵抗温度計の抵抗 值を測定し, 融解温度では熱平衡状態入の移行に緩慢な温度 変化が観測されたため, $4 \sim 6 \mathrm{~h}$ 後に測定した.

\section{3. 測定結果と考察}

\section{1 ネオンの三重点近傍での熱容量測定}

定点測定に断熱カロリメトリーを採用する利点は, 温度計 と試料とを近似的に熱平衡状態にでき, 外部からの寄生熱流 の影響や付着物質を含めた試料容器の熱異常が確認できる 点にあり, 温度定点など相変化の測定法として定着しつつあ る 10) -12). 三重点近傍での熱容量測定の結果を Fig. 1 に示 す．横軸は白金抵抗温度計の抵抗值であり，縦軸は熱容量の 対数である. 三重点以外の温度での熱容量は，ほほ定点セル 容器の熱容量である. 冷凍機内の温度分布が安定であり, ま た，本装置では熱交換ガスを使用していないため，残留ガス の影響がなく, $0.2 \%$ より良い再現性を示した。 また，熱容 量の曲線もなめらかに変化して, 試料以外の付着物などの影 響がないと言える。また，水素の三重点で観測された三重点 近傍での熱異常 7)も観測されていない.

カロリメトリー法に限らず，一般に低温での融解曲線の測 定法は，定点セルにパルス状の熱を加える方法が採用されて いる. 加熱中の定点セルの温度は融解温度より上昇し, 加熱 終了後は温度が低下し, 次第に試料と定点セルが熱平衡状態 になる，この方法では, 融解の開始近傍では温度上昇が小さ く, 短時間でセル全体が熱平衡になり, 融解の終了近傍では 温度上昇が大きく，熱平衡までに長時間が必要となる5), 9). 一般に熱平衡状態になるために必要な時間は, 融解開始近傍 では数 10 分, 終了近傍では 2 時間程度とされている。

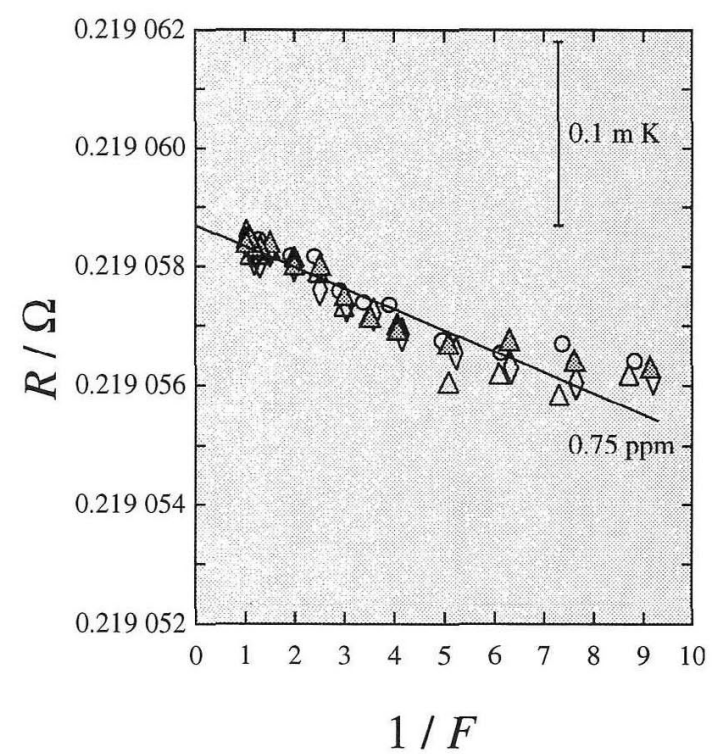

Fig. 3 The relation between the resistances, $R$, of a standard platinum thermometer and the inverse of the fraction of melt, $1 / F$, of the present triple point cell of neon. The impurity concentration of the sample is estimated to be $0.75 \mathrm{ppm}$ from the slope of the solid line, determined by the method of least squares.

今回のネオンの三重点では従来とは異なる現象が観測され た. Fig. 2 は融解中の定点七ルの温度変化を示したものであ る。横軸はパルス加熱後の経過時間であり，縦軸は白金抵抗 温度計の抵抗值の変化である.Fig. 2 では, 加熱後, 融解の 開始近傍 $(F \approx 0)$ では温度の下降が大きく，長い緩和時間 が, 一方, 融解の終了近傍 $(F \approx 1)$ では融解の開始時に比 ベ温度変化も小さく, 短時間で熱平衡状態に回復している. 特に, 融解開始時では加熱後, 熱平衡に達するには $6 \mathrm{~h}$ 以上 必要であり, 従来の報告 ${ }^{5)}$ に比べて 10 倍程度長い.

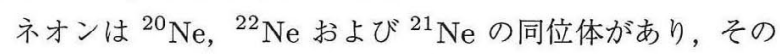
三重点温度は $147 \mathrm{mK}$ 程度の差 ${ }^{13)}$ がある. 天然のネオンはこ れらが, 0.9048, 0.0925, 0.00027 の割合で混合しており, 温 度定点として使われている他の定点物質に比べて特殊な状況 にある.一般に，複数成分の三重点での化学ポテンシャルは， $\mu_{\alpha}\left(p, T, x_{\alpha}\right)=\mu_{\alpha}^{0}(p, T)+R T \ln x_{\alpha}+S_{\alpha}^{0}\left(T-T_{\alpha}^{0}\right)$ で表され, 固相, 液相の平衡条件は, $\mu_{\alpha, l}\left(p, x_{\alpha, l}\right)=\mu_{\alpha, s}\left(p, x_{\alpha, s}\right)$ であ る.ここで, $\mu_{\alpha}$ は成分 $\alpha$ の化学ポテンシャル, $x$ はモル比率, $T$ は三重点温度, $T^{0}, \mu^{0}, S^{0}$ は純粋成分の三重点, 化学ポテン シャルおよびエントロピーである。 ${ }^{20} \mathrm{Ne},{ }^{22} \mathrm{Ne}$ の物性值は正 確に調べられている ${ }^{13)}$ のに対し, ${ }^{21} \mathrm{Ne}$ のデータがないため 天然市オンを 2 成分系と近似し， $x_{\alpha}^{e}$ を有効モル比率で表わし， さらに気体中の成分を無視すると, $x_{20, l}^{e}-x_{20, s}^{e} \approx 0.0008$ と なる，これは融解開始時と融解終了時での液相の組成差であ り, 三重点の温度に換算して約 $0.116 \mathrm{mK}$ の差に相当する. このため Fig. 2 で融解の初期に見られる長時間の緩和現象は, 同位体組成の空間的な再分布に関係するものと推定される。 従来の測定で観測されなかったのは，測定時間が制約されて 
Table 1 Budget of the uncertainty of the present system in calibrating platinum resistance thermometers at the triple point of natural neon

\begin{tabular}{lcc}
\hline $\begin{array}{l}\text { source of } \\
\text { uncertainty }\end{array}$ & $\begin{array}{c}\text { standard } \\
\text { uncertainty/mK }\end{array}$ & $\begin{array}{c}\text { degrees of } \\
\text { freedom }\end{array}$ \\
\hline resistance measurement & 0.005 & 19 \\
thermal equilibrium & 0.029 & 53 \\
self-heating correction & 0.002 & 18 \\
extrapolation to $1 / F=0$ & 0.019 & 53 \\
stability of thermometer & 0.005 & - \\
isotope effect & 0.044 & - \\
\hline combined uncertainty & 0.056 & 131 \\
\hline
\end{tabular}

いたためと思われる。

\section{2 ネオンの三重点}

白金抵抗温度計で測定した融解曲線を Fig. 3 に示す. 横軸 は融解分率 $F$ （全体の試料に対する液体の割合）の逆数であ る. 液相と固相の同位体組成が異なるため融解の進行に伴な い，相平衡温度が変化することを前節で述べた．しかし，こ の変化は $0.116 \mathrm{mK}$ と小さいため, Fig. 3 では $F$ に比例する として近似して補正した。

Fig. 3 の直線は $1 / F<10$ の測定値に対しての近似直線で ある.Fig. 3 の直線からの系統的なずれの主な要因は, Fig. 2

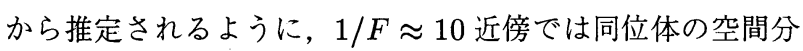
布がまだ平衡でないためと推定される。なお，この直線から 求めた試料の不純物濃度は $0.75 \mathrm{ppm}$ であり, 使用した試料 から推定した純粋試料の三重点は $1 / F=0$ の值である.

\section{3 温度計校正時の不確かさ}

GM 型冷凍機で実現したネオンの三重点で白金抵抗温度計 を校正するときの不確かさを ISO の不確かさの表現法のガ イド ${ }^{15)}$ に従って評価した結果を Table 1 に示す。抵抗測定 の不確かさは計測器の出力信号を統計処理したものである. 自己加熱補正の不確かさは, 測定電流が $2 \mathrm{~mA}$ と $2.8 \mathrm{~mA}$ の ときの測定值から $0 \mathrm{~mA}$ に換算したときの抵抗值の不確かさ であり，抵抗測定の平均值の標準不確かさを $\sqrt{5}$ 倍した。な お, $2 \mathrm{~mA}$ のときの自己加熱による温度上昇は約 $0.06 \mathrm{mK}$ である. Fig. 3 の直線からのばらつきは，主として $F \leq 0.5$ では試料内の温度および同位体分布が, $F \geq 0.5$ では寄生熱 流の影響を反映しており，温度計の示す值と試料の相平衡温 度との違いである。これらをまとめて熱平衡の要因とした。 $1 / F=0$ への外挿值の不確かさ $(0.019 \mathrm{mK})$ は同位体と不 純物の分布の影響によるものである. 温度計の安定度はネオ ンの三重点での測定では観測されなかったが, 水の三重点の 不確かさ $(0.2 \mathrm{mK})$ から換算した值である.同位体組成の影 響は，天然のネオン成分は約 $0.03 \%$ の不確かさがあるため， これを温度値に換算した.なお, 標準抵抗器として $0.1 \Omega$ を 使用したが経年変化は抵抗測定精度より小さいため無視した。 Table 1 では, 同位体組成の不確かさが最も大きく, 従来問 題点として指摘されていた寄生熱流や断熱制御の影響が小さ くなっているのが特徴である。これは冷凍機内の温度分布が
長時間安定であることが主な理由である.

\section{4. 結言}

GM 型へリウム冷凍機を用いて，ネオンの三重点を断熱力 ロリメトリーにより高精度で実現することを試みた。液体へ リウムを使う方法に比べて操作が簡単で, 低温特有の技術が 不要であるなどの特徴がある。ささらに, 長期間一定の低温環 境が実現できるため温度分布が安定で, 導線中の熱起電力の ドリフトが小さく, 精密な断熱制御が可能となり, また, 固 体伝導を使うことにより残留ガスの影響がなく, 定点の測定 としては従来より良い結果が得られた，特に安定な低温環境 は，温度標準の設定など系統的な不確かさを調べるのに適し ている，ネオンの三重点に関しては十分な測定精度が確保で き, 最適な低温定点の実現機器であることが確認できた。

また，同位体の分布に起因すると推定される緩和時間の長 い現象が観測された。三重点の温度值を $0.1 \mathrm{mK}$ より良い精 度で議論するには, 同位体の空間分布と熱平衡の両方を考慮 することが必要であり，これはほかの定点にも言える。

\section{参 考 文 献}

1) Preston-Thomas: The International Temperature Scale of 1990, metrologia 27 3/10(1990), ibid. 27 107(1990)

2) 1990 年国際温度目盛（ITS-90），計量研究所報告 40 $308 / 317(1991)$

3）櫻井弘久：新国際温度目盛，計測と制御 $29268 / 273(1990)$

4）櫻井, 田村, 新井：1990 年国際温度目盛に関する補足情報, 計量研究所報告, 41, 307/358(1992)

5) F. Pavese, et. al.: An International Intercomparison of Fixed Points by Means of Sealed Cells in the Range 13.81 K-90.686 K, metrologia 20 127/144 (1984)

6) O. Tamura and H. Sakurai: Comparison of Tripel Point Temperatures Realized in Two Different Types of Sealed Cells, Jpn. J. Appl. Physics 22 L356/L357(1983)

7）櫻井弘久：GM 型冷凍機による平衡水素の実現, 第 36 回計 測自動制御学会学術講演会予稿集 (1997) $271 / 272$

8）櫻井弘久：GM 型冷凍機を用いた平衡水素の実現, 計測自動 制御学会論文集 36 （1998） 1553/1558

9) A. G. Steele: Cryogenic sealed cells at NRC, Proceedings of TEMPMEKO'96,(Torino 1997) 75/80

10）櫻井弘久：断熱カロリメトリー法による酸素の三重点の実現, 計測自動制御学会論文集 32 1395/1398(1995)

11) A. Szmyka-Grzebyk, H. Manuszkiewicz, L. Lipinski, F. Pavese, D. Ferri, D. Giraudi and P.P.M. Steur: Evidence for Anomalies in the solid-solid phase transitions of oxygen and impurity detection, Proceedings of TEMPMEKO'gO, (Torino 1997) 105/109

12) H. Sakurai: Realization of the triple point of gallium, water and mercury by an adiabatic calorimetric method, metrologia 33 395/399 (1996)

13) G.T. Furukawa: Vapor Pressure of Natural Neon and of the Isotopes ${ }^{20} \mathrm{Ne}$ and ${ }^{22} \mathrm{Ne}$ from the Tripe Point to the Normal Boiling Point, metrologia 8 11/27 (1972)

14) R.E. Bedford, G. Bonnier, H. Maas and F. Pavese: Recommended values of temperature on the International Temperature Scale of 1990 for a selected set of secondary reference points, metrologia 33 133/154 (1996)

15) Guide to the Expression of Uncertainty in Measurement, International Organization for Standard (1993) 